\title{
A Discussion of Chinese Swaddling Culture
}

\author{
Liu Xiaorong, Ma Yunyi \\ Institute of Chinese Language and Literature, Southwest University, Chongqing, China \\ Email: liuxiaorong0908@sina.cn, mayunyi07@gmail.com
}

Received 26 March 2015; accepted 25 May 2015; published 29 May 2015

Copyright (C) 2015 by authors and Scientific Research Publishing Inc.

This work is licensed under the Creative Commons Attribution International License (CC BY).

http://creativecommons.org/licenses/by/4.0/

cc) (i)

Open Access

\begin{abstract}
Every culture has its own swaddling culture. As for China, this swaddling culture can be dated from Shang Dynasty. It is widely employed in not only royal families but also normal families in ancient times, and even till now is still a vital part of Chinese minorities nurturing custom. Swaddle, a long historical nursing product, itself owns a high practical value as well as presenting humanism. Base on ancient literatures and Chinese archaic characters (襁褓), this manuscript will display the unique and profound aspect of Chinese nurturing culture, dispel the misunderstanding of this traditional culture.
\end{abstract}

Keywords

袯褓 Qiang Bao, Swaddle, 子 Zi, Nurturing Custom, Culture

\section{Introduction}

Every culture has its own unique nurturing culture. As a blanket to wrap and carry the infant, 襁袼 qiangbao (swaddle) is "wildly employed in both South America and Japan” (Takabashi, 1989: p. 106). Meanwhile, children from western countries rarely know this subject. The same situation also happens in China. Modern parents in developed area of China hardly employ traditional swaddle (襁褓 qiangbao) to wrap the infant, while ethnic minority groups, especially those live in countryside, still employ this practical as their first gift to the child. 襁

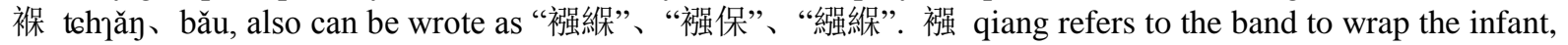
while 褓 bao is the baby blanket. By analysing ancient literatures and archaic characters, we may understand the origin and development of Chinese traditional swaddling custom.

\section{The Origin of 襁褓 Qiang Bao (Swaddle)}

拯褓 qiangbao is an old nursing product. According to the ancient literatures, this object has already been widely used during the Shang Dynasty. We have reason to believe that the origin of this object can be dated back from the initial application time of cloth. 
Liji·Liyun Pian 礼记·礼运篇 has wrote the life of humans in Paleolithic Era: “...Fire was not used, they ate seeds and raw meat of birds and animals, and wore their furs instead of linen and silk... 未有火化、食草之实, 鸟兽之类, 饮其血, 茹其毛, 未有麻丝, 衣其羽皮.” (Dai, 2007: p. 110). When there were no clothes, humans had to cover their bodies with furs, feathers and leaves, and distinct themselves from other tribes with decorations made by shells, animal teeth, and stone balls. When it came to Neolithic Era, humans used simple tools such as bone pins to fasten leather, which maybe the origin of cloth. Shangjun Shu·hua Cepian 商君书·画 策篇 read: “At Shennong's time, men ploughed to get food, women weaved to get clothes. 神农之世, 男耕而 食, 妇织而衣...” (Shang, 2006: p. 206). It is said, Shennong “taught people to plant hemp and mulberry trees to get clothes 教民麻桑以为布帛”, which has changed their custom of “wearing leathers, feathers and leaves 衣其羽皮, 衣其树叶”. At the time of Huangdi 黄帝, Yao 尧 and Shun 舜 (2510BC-2184BC), people cut a hole on a cloth for their heads, and fasten the underarm side with bands. They used a piece of cloth on infants, which may be the origin of 褓 bao (baby blanket).

Chinese traditional swaddling culture can be proved by ancient characters. The pictorial nature of Chinese characters ensures them being able to compare with modern objects, as well as giving a vivid insight into the lives in ancient China. Hence, studying the structure and meaning of Chinese script allows us to get closer to the origin and development of Chinese traditional culture.

The character 襁 qiang is recorded in the following ancient literatures. Lunyu·Zilu 论语·子路 wrote: “Now, when these things obtain, people from all quarters will come to him, bearing their children on their backs what need has he of a knowledge of husbandry 夫如是，则四方之民，襁负其子而至矣，焉用稼?” (Confucius, 2011: p. 214). Mozi·minggui xia 墨子·明鬼下 recorded: “Bao is still small and in his swaddle-clothes 鲍幼弱, 在荷襁之中.” (Mohists, 2015: p. 247). In the mean time, the character 襙 qiang is recorded in the radical 衸 section of book Shuowen, explained as a band to carry the infant, pronunciation given as the onset of 衣 with final of 强 qiang 襁, 负儿衣, 从衣强声 (Xu, 1963: p. 170). This has proved that 襁 qiang is a phonon-semantic compounds character (xingsheng 形声字), hence is a kind of cloth. Li Shan’s 李善 (630 AD-689AD) annotation about Wenxuan·bowu zhi 文选·博物志 has explained 襁: “a weaved cloth with a width about 2.4 metres (There are two measurements in Tang Dynasty. Here we prefer dachi 大尺 instead of xiaochi 小尺, 1 cun $=0.29$ metres ( $\mathrm{Wu}, 1992)$ ) of a length of about 3.9 metres, used to bind the infant on the back. 襁, 织缕为之, 广八寸, 长丈二, 以约小儿于背上.” (Xiao, 1986: p. 1372). From which we can draw a conclusion that 褆 qiang is a special nursing cloth to bind and carry infant on the back. In addition, in Chinese culture red symbolizes joy, as a result, a red band (襁 qiang) is usually used to wrap the infant, as in Figure 1.

The application of 褓 bao (baby blanket) can be proved with oracle bone inscriptions. The known oracle bone inscriptions include the sign 保 bao instead of the sign 褓 bao, as: 伊合 3481 and 合 18970, look like an adult holding an infant in the arms, protecting him. As it comes to the Spring and Autumn and Warring State periods, the sign became more pictorial, like an adult carrying an infant on the back. Gradually it simpli-

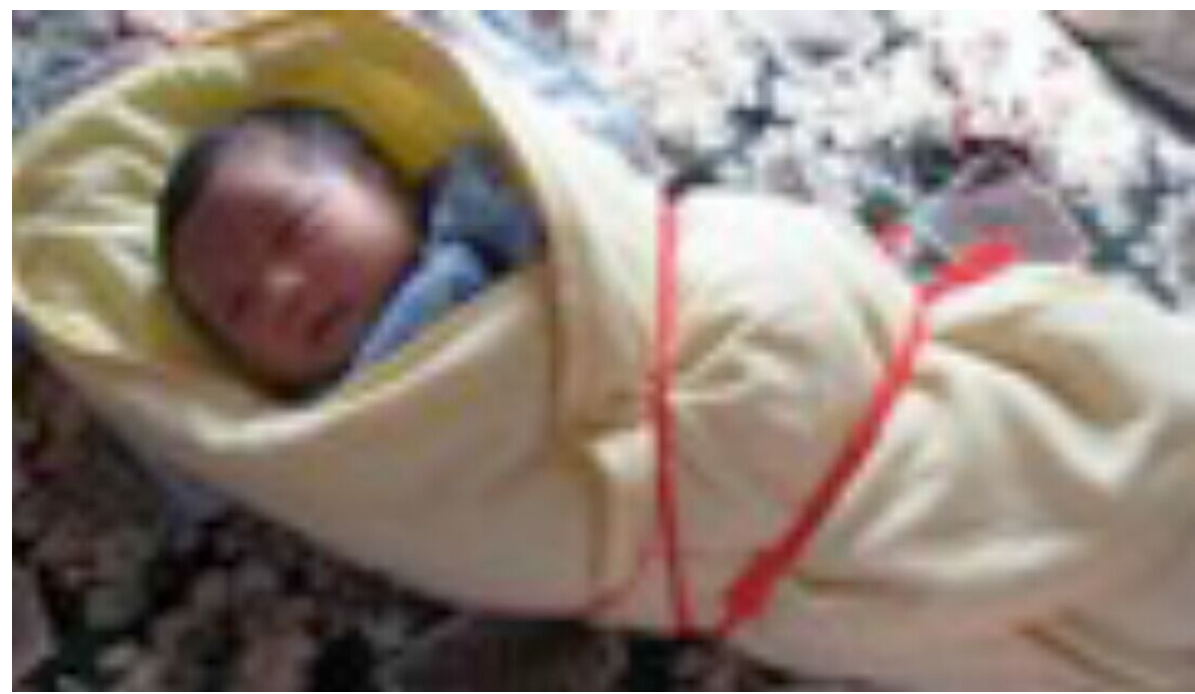

Figure 1. A red band (褆 qiang) is usually used to wrap the infant. 
fied the bind belt to a 政 pie [the left-falling stroke]: 保, To stylize the sign, a 捺 na [the right-falling stroke] was added on the left: 保 (Si Kou Liang Fu meals container 司寇良父篮, late Zhou Dynasty); 菌 (Bao Shan212 包山 212, Warring State period); (Ju Hou Vessel 莒侯篮, Spring and Autumn period) (Gao \& Tu, 2008). This indicates that in the Oracle bone period, the sign 保 bao originally worked as a verb, meaning bear and protect, as in Liji·Yueling 礼记·月令: “ On a chose auspicious day, the king himself carried the ploughs and plowshares, and put it between the armed, protected hourse and the coachman 乃择元辰, 天子亲载来诟, 措之参保介之御间.” (Dai, 2007: p. 116). On which Kong Yingda 孔颖达 (574AD-648AD) has noted the character 保 bao as the verb protect. As time goes on, it has been used as rebus to explain the meaning of baby's blanket, 袺 bao as well as 綝 bao are also found in the radical 糸 section of book Shuowen, explained as baby clothes, recorded with the pronunciation given as the onset of 糸 mi with final of 保 bao 綝, 小儿衣也, 从系保声 (Xu, 1963: p. 275). In conclusion, the character 褓//綝 bao is created by modifying 保 bao with a determinative $x^{k}$ or 糸. 保 bao is the original character when express the meaning of baby blanket. The same as 襁 qiang, the baby blanket is always red and floral, symbolizing joy and lucky, as showed in Figure 2.

These analysizes imply that ancient Chinese used the swaddling band (襁) to restrict and bind infant, and the baby blanket (褓) to wrap infant. The swaddling band (襁) and baby blanket (褓) are usually employed together, as a result, the joint word 褆褓 qiangbao or 繦綝 qiangbao is formed. This joint can be proved by the oracle bone sign 子 zi. Studying of the oracle bone scripts has proved that the character 子 zi appeared in Shang Dynasty (Guo \& Hu, 1978-1982), with two main signs: 古 and 㞥, both highlight the feature of a baby: one big head, two waving arms. The one leg in the sign results from the legs restricted by swaddle. As a zodiograph, this sign of "zi" represents the infant swaddled, waiting to be fed. This Chinese traditional "candle-shaped package" have also been widely found as grave goods in the Maiji Mountain Grottoes, as in Figure 3: Tang Dynasty, Han Senzhai 韩森寨 Tomb, Maiji Mountain Grottoes’ 麦积山石窟 swaddled baby statue. The jade artifact found in an Eastern Han dynasty tomb also indicates the universality of this Chinese cultural practice, as showed in Figure 4.

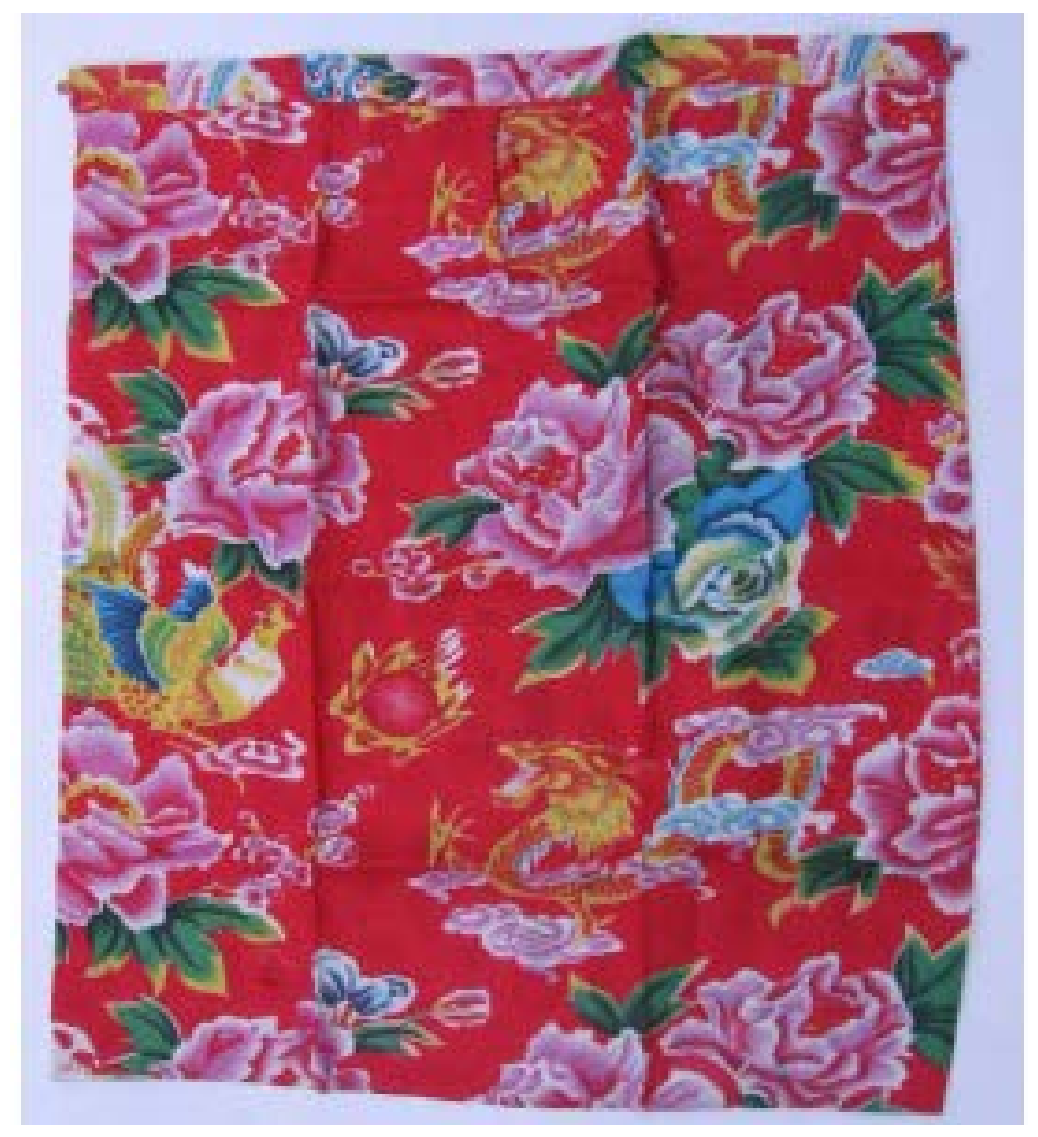

Figure 2. Red and floral baby blanket, symbolizing joy and lucky. 


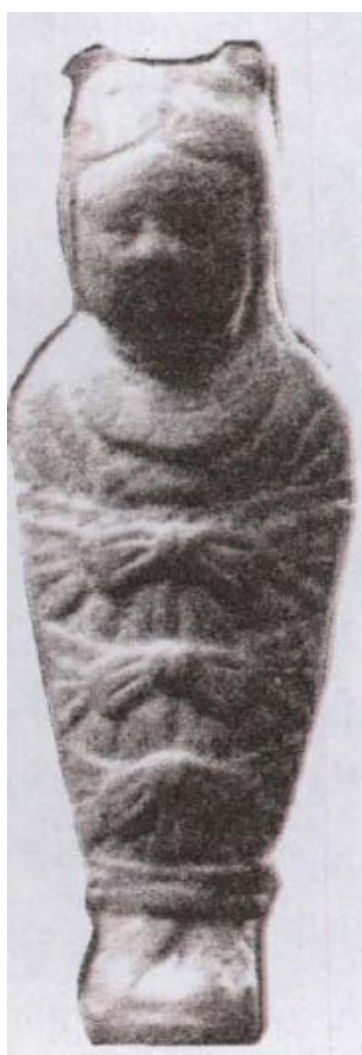

Figure 3. Maiji Mountain Grottoes’ swaddled baby statue.

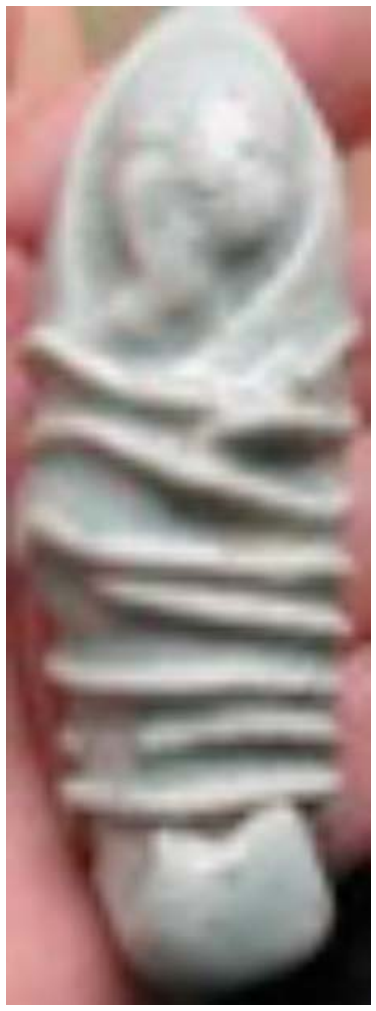

Figure 4. Jade artifacts found in an Eastern Han dynasty tomb. 


\section{Chinese Swaddling Culture}

The word 褆褓 qiangbao has proved the long history of Chinese traditional swaddling practice, as well as the broad employment of this practice, not only in the royal families, but also in the normal families.

As found in the ancient literatures below. Jia Yi 贾谊 (200BC-168BC) wrote in Xinshu 新书: “ In the ancient time, when the King Cheng of Zhou was a swaddled baby, Zhao Gong (Duke Zhao of Yan) was Tai Bao (Gran Protector),Zhou Gong( Duke of Zhou) was Tai Fu(Grand Tutor), Tai Gong (Duke Tai of Qi) was Tai Shi (Grand Preceptor) 昔者, 周成王幼在“襁褓”之中, 召公為太保, 周公為太傅, 太公為太師.” (Jia, 2011: p. 63). Wang Chong 王充 (27AD-fl.) wrote in Lunheng·Chubing Pian 论衡·初禀篇: "When Chang was a swaddled baby, the auspicious sign had showed 昌在襁褓之中, 圣瑞见矣.” (Wang, 2006: p. 54). 昌 chang is Ji Chang (姬昌), the name of King Wen of Zhou. Hanshi waizhuan 韩诗外传 vol.3: “Fathers will not lose their sons, elder brothers will not lose their little brothers, and no one will not take their responsibility of raising babies 父不哭子, 兄不哭弟, 道无襁负之遗育” (Han, 1980: p. 29). Even in this modern time we can still find this practice in some countryside of China, as showed in Figure 5.

From ancient times, Chinese pays a lot of attentions on carrying their off springs, thus has a distinctive perspective on nurturing. Chinese ancients wrap their babies with blanket 褓 bao, and carry their babies on their back with the band 襁 qiang; or use the band 襁 qiang to bind the babies and put them in the cradle or in the mother's arms. This way of rasing is simplified, however, comfortable and safe. This nurturing practice is decided by the mode of production and lifestyle in the time when most of the people have to work hard to live. With their hands free, parents can continue their productions. And as a result, elder siblings take care of brother or sisters when their parents went to work, as in Figure 6.

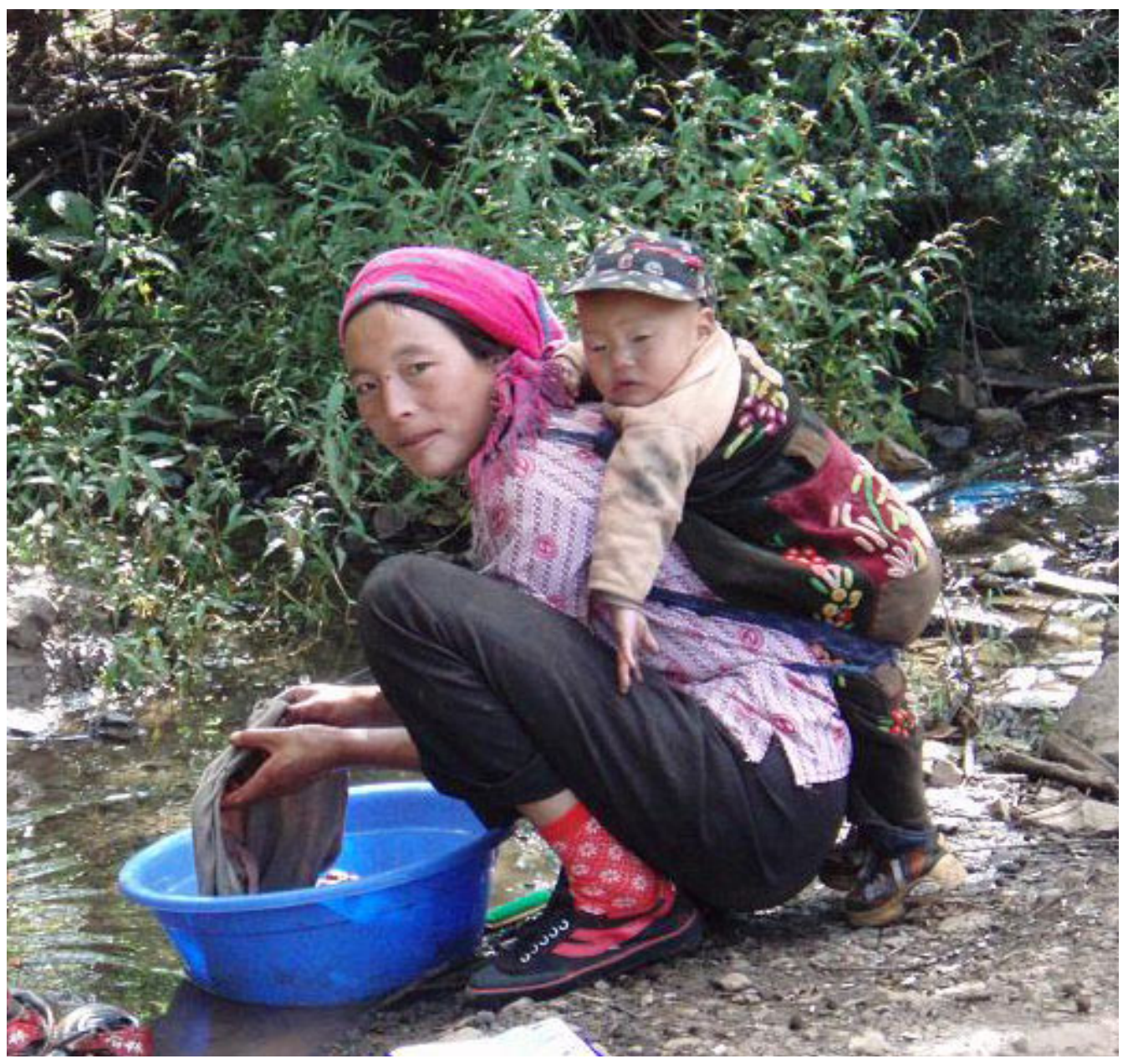

Figure 5. Baby swaddled in some countryside of China. 


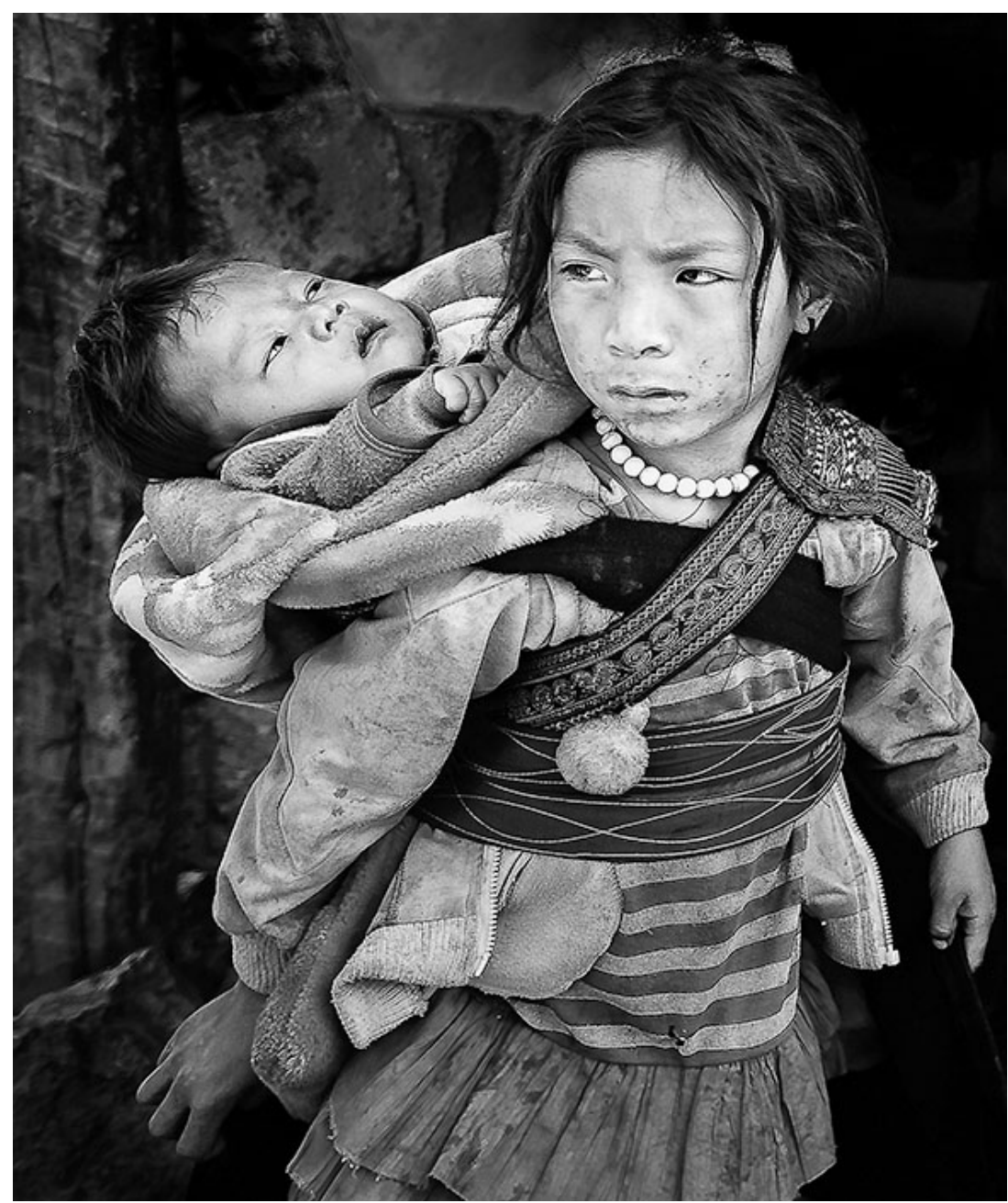

Figure 6. Elder siblings take care of brother or sisters when their parents went to work.

In China, because of the distinctive features appearing in various ages, there are specific words corresponding to related ages, as childhood was called “总角 zongjiao”, the girls in age 12-13 was called “豆冦 doukou”, males at their 20th was called “弱冠 ruoguan”. The reason childhood was called 总角 zongjiao is that juveniles in Ancient China bundled their hair into the shape of "horn 牛角 niujiao" (Liu, 2012). The same goes to 沀褓 qiangbao. As a result of the expansive employment of swaddle 襁褓 qiangbao, the infant at age 0-1 was called 褆褓 qiangbao.

Meanwile, the restrictiveness of the tool swaddle (褆褓 qiangbao) has linked the word to this extensive meaning as "the tool to protect or restrict", as demonstrated in the titles below: "Judicature: Walking out of politics Swaddle 司法: 走出政治的襁褓” (Zhang, 2005); In addition, as a tool to wrap the new-born baby, 䘦袺 qiangbao is extensively used to express 'something just start out' as in: "Bronfenbrenner's Concept of Human Development: From Cradle to Maturity 布朗芬布伦纳从襁褓走向成熟的人类发展观” (Gu, Wang, \& Qin, 2012).

Along with the time, swaddle 褆褓 qiangbao, originally a simple objective practice, has become to a subjective way of judgment. The simple restrict to the body has been attached to the mold of the infant's characteristics and behaviors. Chinese believe that if wrapped properly, the newborns will not end up in doing evil things. Until now, when a curious child got in trouble, elders will blame that "they are not bound properly when they were an infant. "This way of considering that swaddle 襁褓 qiangbao will affect the behavior and characteristic of a new born has fermented and resulted in series of new-born rituals.

Chong Yi 崇彝 in Qing Dynasty has recorded a tradition to wash the infant on his third day 三日洗儿, 谓 
之洗三, in Daoxian Yilai Chaoye Zaji 道咸以来朝野杂记 (Xu, 1999). This ritual looks like the sign 出 found on Fu Yi Meng vessel 父乙孟触. “After washing the infant, a ritual called 'sanzhaofengshou' is performed. The parents will tie the infant's hands separately with two red bands, or sew the cuff up. Boys on the left side, and girls on the right side. This ritual is to wish peace, and 'restrict' the baby so that he will follow the path and stay away from evil things 洗过之后, 要进行‘三朝封手’ 的仪式, 家长用两条红带将婴儿的双手 分别系起, 也有的是事先缝合袖口的衣衫。男孩封左手, 女孩子封右手。封手之意在于使小儿安宁, 对孩 子‘严加管束’，长大后能够规矩做人”.

\section{Traditional Swaddling Culture in Crisis}

Chinese traditional swaddling culture is gradually replaced by nursing cultures from other countries, and only reserved in minorities live in southwestern China. This is most because that modern parent's espousing in western cultures believes that with their limbs free, infant's development becomes unlimited, and personality becomes “progressive and open-minded”. Just as Li Xu 李旭 believes: “Although an inexpensive, convenient way of keeping warm, swaddling leads to a restriction of the infant's movement, thus swaddled infant always appears to be quiet and lack of movements. This may related to Chinese reserved and conservative personality; on the other hand, people in western countries expose their babies into an unrestricted circumstance, does this somehow explain the progressive and openness in their personalities 襁褓是一种符合中国国情的方便、廉价 的保暖措施, 但是其必然对宝宝的四肢活动产生一定的限制作用, 襁褓内的孩子总是显得安静且活动少, 从人性学的角度而言, 这或许与中国人的含蓄、内玫的个性不无关系; 而西方人种从新生儿时, 便被置 于一个不受束缚、无无拘无束的环境中, 又是否恰恰彰示了其自由、奔放和张扬的个性呢?” (Li, 2009). On the contrary, literatures presented in chapter 2 demonstrated a time when emperors and high-positioned officials were all swaddled. With their great efforts, ancient China had become one of the powerful countries in the world. From this point of view, Li Xu may be a bit lop-sided.

Furthermore, pediatrics expert from Beijing Hospital of Chinese Medicine, Professor Wang Yinglin 王应麟 believes: “An unsaddled infant doesn't sleep well. The newborns had been curled up in the wombs of their mothers for a long time, thus they stay in this position after born. However, the limbs will stretch during their development, and this swaddling practice help them to adapt to the new position 新生儿不入襁褓睡眠质量差 由于新生儿长期蜷曲于母体, 出生后仍保持这一姿势, 而成长中的肢体是要放开的, 所以这种入襙袺的 做法是帮助其适应新的肢体顺直的状态.” (Ye, 2006). This explains that why unsaddled western infants always sleep with their limbs curl like a frog, leading to a low level of sleep qualities, as well as affecting the development of thoraces.

Ancient Chinese approved that the newborns "need to be swaddled in a proper way 必须入裪褓, 襁褓之道, 必须得宜”. Over tight will lead to a block in the blood circulation, and slow down the body development. Expert suggests "put cotton clothes on the infant, wrap them properly until their limbs can have subtle movements in cotton blanket 可以给婴儿穿上小布衫, 再用薄棉被或布单适当裹紧, 让小胳膊小腿有一点活动余地.” (Ye, 2006).

Another merit of the swaddle is that it is hard to be wriggled out so that can prevent the baby from suffering cold and catching respiratory and digestive tract diseases. As proved by Professor Liu Kun's (刘坤) statistical findings: "the rate for swaddled newborns to catch cold and fever, diarrheas and abdominal pain is $1 / 3$ lower than that of normal blanket 家庭护理新生儿, 使用家庭式襁褓的新生儿的感昌发烧、腹痛腹泄发生率比 用普通抱被低出 1/3 以上.” (Liu, 2014). Especially when a newborn’s body suffers subtle development problems, traditional swaddling practice can help to correct them due to the softness and flexibility of the body.

Chinese ancestors observed that the newborns keep their limbs curl up and tense as they were in the mothers' wombs, as Gong Tingxian 龚廷贤 (1522-1619) in Ming Dynasty wrote in the comprehensive medical book Shoushibaoyuan, “it is better to swaddle them 宜绑缚令卧” to help the limbs stretch, keep warm and prevent them from being terrified.

Chinese swaddling practice formed in Shang Dynasty, has been passed down to generations through years. Like other Chinese traditions, this practice is facing a perish crisis under the pressures from western cultures. With its scientificity and usefulness, this traditional swaddling practice should be continually folklore.

\section{References}

Confucius’ Followers Complied (2011). Lun Yu 论语 (Mao Zishui 毛子水 Annotated) (p. 214). Chongqing: Chongqing Chubanshe. 
Dai Sheng 戴圣 (fl. Han Dynasty) (Comp.) (2007). Xiaodai Liji 小戴礼记 (Hu Pingsheng 胡平生, Chen Meilan 陈美兰 Trans.). Beijing: Zhonghua Shuju.

Gao Ming 高明, Tu Baikui 涂白奎 (2008). Gu wenzi leibian zengdingben 古文字类编增订本. Shanghai: Shanghai Guji Chubanshe.

Gu Yu 谷禹, Wang Lin 王玲, Qin Jinliang 秦金亮 (2012). Bronfenbrenner’s Concept of Human Development: From Cradle to Maturity 布朗芬布伦纳从褴褓走向成熟的人类发展观. Xinlixue tanxin, 2, 104-109.

Guo Moruo 郭沫若, Hu Houxuan 胡厚宣 (Eds.) (1978-1982). Jiaguwen Heji 甲骨文合集. Beijing: Zhonghua Shuju.

Han Ying 韩贞 (Comp.) (1980). Hanshi waizhuan jishi 韩诗外传集释 (Xu Weiyu 许维逥 Annotated.) (p. 29). Beijing: Zhonghua Shuju.

Jia Yi 贾谊 (2011). Xin shu 新书 (p. 63). Jiangsu: Fenghuang Chubanshe.

Li Xu 李旭 (2009). Manhua “qiangbao”漫话“襁褓”. Muying Shijie, 12, 38-39.

Liu Kun 刘坤 (2014). Jiatingshi qiangbao zai erke hulizhong de zuoyong 家庭式襁褓在儿科护理中的作用. Huli Yanjiu 护理研究. Yunnan: Chuxiong Yiyao Gaodeng Zhuangke Xuexiao, 273.

Liu, J. R. (2012). Analysis of “zongjiao” in Shijingmeng. Journal of Shaoxing University, 32.

Mohists Compiled (2015). Mozi 墨子 (Fang Yong 方勇 Trans.) (p. 247). Beijing: Zhonghua Shuju.

Shang Yang 商鞅 (2006). Shangjun shu 商君书 (Zhang Jue 张觉 Annotated) (p. 206). Changsha: Yuelu Shushe.

Takabashi Etsujirou 高橋悦二郎 (1989). Taijiao he yujing (Bu Mujun 卜目钧, Trans.) (p. 106) Shanghai: Shanghai Kexue Jishu Chubanshe.

Wang Chong 王充 (27AD-fl.) (Eds.) (2006). Lun Heng 论衡 (Cheng Puqing 陈蒲清 Annotated.) (p.54). Changsha: Yuelu Shushe.

Wu Hui 吴慧 (1992). Weijin nanbei chao suitang de duliangheng 魏晋南北朝隋唐的度量衡. Zhongguo shehui jingji shi yanjiu 中国社会经济史研究, 3.

Xiao Tong 萧统 (Comp.), Li Shan 李善 (Annotated) (1986). Wen Xuan 文选 (p. 1372). Shanghai: Shanghai Guji Chubanshe.

Xu Shen 许慎 (Comp.), Xu Xuan 徐铉 Annotated (1963). Shuowen jiezi 说文解字. Beijing: Zhonghua Book Company.

Xu Xing 许星 (1999). Zhongguo chuantong ertong fushi xisu de xingshi yu neihan chutan 中国传统儿童服饰习俗的形式 与内涵初探. Suzhou sichou gongcheng xueyuanbao, 6, 17.

Ye Yi 叶依 (2006). Youren ba haizi guodejin youde ba baobao fangdekai xinsheng baobao haiyao guo qiangbao ma 有人 把孩子裹得紧 有的把宝宝放得开 新生宝宝还要裹襁褓吗. Jiangkang shibao yingyou baojian, 12, 1.

Zhang Chengguang 章乘光 (2005). Sifa: Zouchu zhengzhi de qiangbao 司法: 走出政治的襁褓. Master Thesis, Shanghai: East China University of Political Science and Law. 